\title{
Szenes anyagok maximális átalakulási hômérsékletének meghatározása Raman-spektroszkópiai mérésekkel: standardizálás és esettanulmány az Aggtelek-Rudabányai-hegységból
}

\author{
Molnár Kata ${ }^{1}$, Aradi László Előd ${ }^{2}$ *, OBbÁGy Gabriella ${ }^{1,3}$, Kövér Szilvia ${ }^{4}$, Fodor László ${ }^{4,5}$, Benkó Zsolt ${ }^{1}$, SzABó Csaba ${ }^{2}$ \\ 'Izotóp Klimatológiai és Környezetkutató Központ, Atommagkutató Intézet, Debrecen (molnar.kata@atomki.hu, obbagy.gabriella@atomki.hu, \\ benko.zsolt@atomki.hu) \\ ${ }^{2}$ Litoszféra Fluidum Kutató Laboratórium (LRG), Kőzettani és Geokémiai Tanszék, Eötvös Loránd Tudományegyetem, Budapest \\ (aradi.laszloelod@gmail.com, *corresponding author, cszabo@elte.hu) \\ ${ }^{3}$ Ásvány és Földtani Tanszék, Debreceni Egyetem, Debrecen \\ ${ }^{4}$ MTA-ELTE Geológiai, Geofizikai és Ürtudományi Kutatócsoport, Budapest (koversz@ gmail.com) \\ ${ }_{5}^{5}$ Általános és Alkalmazott Földtani Tanszék, Eötvös Loránd Tudományegyetem, Budapest (lasz.fodor@yahoo.com)
}

\section{Peak metamorphic temperature determination by Raman spectroscopy of carbonaceous materials: standardization and case study from the Aggtelek-Rudabánya Hills}

Abstract

Peak metamorphic temperature estimates by illite (i.e. Kübler index), chlorite "crystallinity" and vitrinite reflectance exhibit a high degree of uncertainty in case of deep diagenetic to low-grade metamorphic rocks. During the last decade, Raman spectroscopy of carbonaceous materials (RSCM) has become a widespread method for obtaining more precise temperature estimates. The aim of this study is to introduce the theoretical background and applicability of one of the most promising RSCM methods in Hungarian literature. The presented method is based on a calibration curve of a reference series; this series provides an estimation of peak metamorphic temperatures of unknown samples. The application of this reference series enables a comparison to be made of the temperature results with data from other laboratories using the same reference series. In this work, we present the results of the reference series measured at the ELTE TTK KKIC Raman laboratory, along with the computed calibration curve. The applicability of the method is demonstrated using the example of the Telekesoldal Formation of the Aggtelek-Rudabánya Hills. The estimated peak metamorphic temperature of the complex is $273 \pm 10^{\circ} \mathrm{C}$, which considerably refines the estimations of previous methods: e.g. illite (Kübler index), chlorite "crystallinity" and vitrinite reflectance values. The method described here can either expand, or partially replace the vitrinite reflectance measurements, with respect to hydrocarbon and coal exploration and research.

Keywords: STA-RSCM, vitrinite, peak metamorphic temperature, structural geology, Carpathian-Pannonian region, Aggtelek-Rudabánya Hills, Telekesoldal Formation

Összefoglalás

A mély diagenetikus - kisfokú metamorf üledékes kőzetek csúcshőmérsékletének meghatározását illit (Küblerindex) és klorit „kristályossági”, valamint vitrinit reflexiós értékek alapján nagy bizonytalanság terheli. A hőmérséklet pontosabb meghatározására az elmúlt időszakban egyre elterjedtebbé vált a szenes anyag szemcsék mérésén alapuló Raman-spektroszkópia. Jelen munka célja, hogy a szenes anyag Raman-spektroszkópia (RSCM) egyik módszerének alapjairól, valamint hazai alkalmazási lehetôségeiről adjon részletes, magyar nyelvú összefoglalást. A bemutatott módszer alkalmazásához elengedhetetlen egy ismert metamorf csúcshőmérsékletú referencia kőzetsorozat elemzése, amely az ismeretlen minták metamorf csúcshőmérsékletének meghatározásához szükséges kalibrációs görbe alapjául szolgál. Ez a referencia kőzetsorozat teszi lehetővé az egyes laboratóriumokban született eredmények összehasonlíthatóságát is. Munkánkban ismertetjük az ELTE TTK KKIC Raman-laboratóriumában mért referencia kőzetsorozat eredményeit, valamint az ez alapján létrehozott kalibrációs görbét. A módszer alkalmazhatóságát az Aggtelek-Rudabányai-hegység Telekesoldali Formációjának példáján mutatjuk be. Az öt mintán (négy fúrás, egy felszíni) elvégzett mérések alapján az összletre meghatározott metamorf csúcshőmérséklet $273 \pm 10^{\circ} \mathrm{C}$-nak adódott, amely adat jelentôsen pontosabb a korábban rendelkezésre álló illit- és klorit kristályossági, valamint vitrinit reflexiós értékek alapján becsült metamorf csúcshőmérsékleti értékeknél. A módszer kitúnően kiegészíti, valamint részben helyettesítheti a szénhidrogén-, illetve széngeológiában alkalmazott vitrinit reflexió méréseket.

Tárgyszavak: STA-RSCM, vitrinit, metamorf csúcshömérséklet, szerkezetföldtan, Kárpát-Pannon térség, Aggtelek-Rudabányai-hegység, Telekesoldali Formáció 


\section{Bevezetés}

A szenes anyagok Raman-spektroszkópiája (RSCM, Raman spectroscopy of carbonaceous materials; PASTERIS \& WOPENKA 1991, BEYSSAC et al. 2002) az éretlen szerves anyag kristályos grafittá történő átalakulását, annak egyes fázisait vizsgálja. Ez az átalakulás egy irreverzibilis folyamat, amelynek mértéke elsősorban a hômérséklettől függ, ezért különböző átalakultsági fokú szenes anyag szemcsék Raman-spektruma alkalmas a szemcséket tartalmazó üledékes kőzetek metamorf csúcshőmérsékletének meghatározására. Ezen alapszik például BEYSSAC et al. (2002) 330 és $650{ }^{\circ} \mathrm{C}$ közötti tartományban alkalmazható, empirikus geotermométere, amely széles körben elterjedté vált ebben a hőmérsékleti tartományban (pl. BEYSSAC et al. 2007, SCHARF et al. 2013, MÉszÁros et al. 2016). Az újabb tanulmányok kísérletet tettek a kisebb hômérsékletek $\left(<350{ }^{\circ} \mathrm{C}\right)$ meghatározására is (RAHL et al. 2005, LAHFID et al. 2010, KouKETSU et al. 2014), így a módszer által vizsgálható hőmérsékleti tartomány $165-655{ }^{\circ} \mathrm{C}$-ra bővült. A mérés, adatfeldolgozás és -kiértékelés azonban sok tényezőn - többek között a mintaelőkészítésen, a Raman-spektrométer paraméterein (pl. használt lézer hullámhossza, teljesítménye) és az operátoron (pl. görbe és alapvonal illesztéséhez használt függvény, Raman-spektrum kiértékelése) is - múlik, ami megnehezíti az egyes laboratóriumokban született eredmények összehasonlíthatóságát (LÜNSDORF et al. 2014). Ezen hatások minimalizálására dolgozott ki LÜNSDORF \& LÜNSDORF (2016) egy spektrumfeldolgozó algoritmust (IFORS, Iterative fitting of Raman spectra) és egy geotermométert (STA-RSCM, scaled total area-RSCM; LÜNSDORF et al. 2017). Az algoritmus segítségével a spektrumok kiértékelése automatizálható. A geotermométer pedig egy referencia kőzetsorozaton alapul, amelynek független módszerekkel meghatározott metamorf csúcshőmérsékletû mintáit lemérve lehetôvé teszi, hogy minden egyes labor létre tudja hozni a saját kalibrációs görbéjét. Jelen tanulmányban e módszer bemutatását, az általunk létrehozott kalibrációs görbét, valamint egy esettanulmányon keresztül a módszer alkalmazásának szemléltetését tűztük ki célul. A termométer alkalmazását a Telekesoldali Formáció (Aggtelek-Rudabányai-hegység), egy kisfokú metamorfózison átesett összlet példáján mutatjuk be. Munkánk során teszteltük azt is, hogy a szenes anyag szemcsék mérési eredményeiből számolt hőmérsékletek összhangban vannak-e a már korábban meghatározott hőmérsékleti tartományokkal, valamint, hogy a Raman-spektroszkópia segítségével lehetséges-e a hőmérsékleti értékek pontosítása, a hőmérsékleti tartományok szúkítése.

\section{Raman-mikrospektroszkópia alapjai}

Az elmúlt időszakban számos spektroszkópiai anyagvizsgálati módszer terjedt el a geológiában, különösen az ásványtan, kőzettan és geokémia területén (pl. RosASCO \& RoEDDER 1979 - Raman; Rossman 2006 - FTIR). Ezek hagyományosan a vizsgálandó anyag által elnyelt vagy kibo- csátott elektromágneses sugárzás elemzésén alapulnak, amelyek segítségével jellemezhetôvé válnak az anyag fizikai és kémiai tulajdonságai. Ezen módszereken belül külön csoportot alkotnak a rezgési spektroszkópiai módszerek, amelyek alkalmazása során az anyagban lévő kötések és a besugárzásra használt elektromágneses hullámok kölcsönhatását tanulmányozzuk (VÁczi 2011). A Raman-spektroszkópia esetében a gerjesztő sugárzás általában a látható fény tartományába esik (jellemzően közeli ultraibolyától a közeli infravörösig); ennek a sugárzásnak a rugalmatlan szóródását tanulmányozzuk a vizsgált minta anyagi rezgésein (VÁCZI 2011). A spektrumban megjelenő sávokat az adatbázisban szereplő spektrumokkal összehasonlítva azonosíthatóvá válik a minta (pl. RRUFF; LAFUENTE et al. 2015), aminek fizikai (pl. nyomás, hibasúrúség) és kémiai paramétereire (pl. elemhelyettesítések) is következtethetünk. Általános körülmények között alkalmazva roncsolásmentesnek tekinthető a módszer. A méréshez sok esetben nem szükséges mintaelőkészítés, így olyan, különböző halmazállapotú és eredetú minták vizsgálata is lehetôvé válik, amelyek preparálása nehézkes vagy nem lehetséges (pl. régészeti leletek, mútárgyak, speciális geológiai és biológiai minták). A Raman-spektrométerhez mikroszkópot szerelve (mikrospektroszkópia) a lézerfény igen kis területre, $\sim 1 \mu \mathrm{m}$ átmérőjú foltra fókuszálható, így nagy térbeli felbontással végezhetők az elemzések és térképek is készíthetők automatizáltan.

\section{Szenes anyagok Raman-spektroszkópiája}

A szenes anyag szemcsék Raman-spektroszkópos vizsgálata (RSCM) információt szolgáltathat a szenes anyagok érettségéról (pl. WOPENKA \& PASTERIS 1993), az ebból kapott adatok pedig több empirikus geotermométer alapját is képezik (pl. BEYSSAC et al. 2002, RAHL et al. 2005, AoyA et al. 2010, KouKETSU et al. 2014). Ezen termométerek azonban bizonyos analitikai és mintaelőkészítési körülmények miatt hibával erősen terheltek (LÜNSDORF 2016). A szenes anyag Raman-spektrumát ugyanis erôsen befolyásolja a szemcse orientációja (Bustin et al. 1995, BARZOI 2015), a használt lézer hullámhossza és teljesítménye (pl. VIDANO et al. 1981), a minta felszínének polírozása (WOPENKA \& PASTERIS 1993, BEYSSAC et al. 2003, CREsPo et al. 2006, AMMAR \& RouZAUD 2012), valamint a háttér- és csúcsillesztés módszere (pl. BEYSSAC et al. 2002, SADEZKY et al. 2005, LAHFID et al. 2010). A fenti hibaforrások kiküszöbölésére LÜNSDORF \& LÜNSDORF (2016), valamint LÜNSDORF et al. (2014, 2017) egy új, standardizált módszert dolgoztak ki, ami alkalmas az érettség és a metamorf csúcshőmérséklet meghatározására. Az általuk bemutatott módszer része egy referencia kőzetsorozat, a mintaelőkészítési protokoll, a használt lézer javasolt hullámhossza (jelenleg 488 nm-re és 532 nm-re van kidolgozva), valamint a Raman-spektrum feldolgozási módja (LüNSDORF et al. 2017). Utóbbihoz egy teljesen automatizált háttér-, valamint csúcsillesztési protokoll tartozik (IFORS; LÜNSDORF \& LÜNSDORF 2016), ami kiküszöböli az adatkiértékelés és -feldolgozás során felmerülő operátori, felhasználói szubjektivitást. 
A szenes anyagok megfelelő polírozása nemcsak a vitrinit reflexió méréséhez elengedhetetlen, hanem a Ramanspektroszkópos érettség meghatározásához is feltétlenül szükséges. Ennek oka, hogy a Raman-mérések során látható fényt használunk, így a fény csak az opak szenes anyag szemcsék felszínközeli zónáiba $(<1 \mu \mathrm{m})$ tud behatolni. Az információ is ebből a felszíni rétegből fog származni. A szenes anyag szemcsékre kis keménység és könnyú deformálhatóság jellemző, a nem megfelelő polírozás pedig befolyásolhatja a szenes anyag szerkezetét, így annak Ramanspektrumát is (MCCREERY 2005). Több korábbi munka is próbálta elkerülni a polírozás deformáló hatását. BEYSSAC et al. (2003) átlátszó ásványok alatt (azaz nem a csiszolat felszínén) lévő szemcsék vizsgálatával, RANTITSCH et al. (2004) pedig a szenes anyag szemcsék kémiai leválasztásával igyekeztek ezt megvalósítani. Azonban az első módszer sokszor nem kivitelezhetô például finomszemcsés (agyagos-aleurolitos) kőzetekben, a másodikként említett eljárás alkalmazásával pedig fontos szöveti információt veszíthetünk el (LÜNSDORF 2016).

A szenes anyag szemcsék mérése különleges, ugyanis a mérés során használt lézer hullámhosszától függ a Ramanspektrumuk helyzete (a lézer hullámhosszának növekedésével csökken a csúcspozíciók Raman-eltolódása; pl. VIDANO et al. 1981, PócSIK et al. 1998, FERRARI \& ROBERTSON 2001), valamint a fluoreszcens háttér is, ami nagyban megnehezítheti a szenes anyag szemcsék Raman-spektrumának elemzését. Mindezeket a jelen munkában alkalmazott LÜNSDORF \& LÜNSDORF (2016)-féle kiértékelő szoftver figyelembe veszi. Munkánk során a LÜNSDORF et al. (2017) által bemutatott mintaelőkészítési és mérési protokollt követtük, amelynek főbb pontjai az alábbiak:

- A múgyantába ágyazott felületi csiszolatot (kis metamorf csúcshőmérsékletű minták esetében; $<300{ }^{\circ} \mathrm{C}$ ), illetve a vékonycsiszolatot $\left(>300^{\circ} \mathrm{C}\right.$; kékpala, zöldpala, illetve nagyobb metamorf fáciesú minták) a rétegződésre/foliációra merólegesen készítsük el.

- A múgyantába ágyazott mintákat fokozatosan csiszoljuk (ideális esetben P400 $\rightarrow$ P2500-as SiC csiszolópapírokon), majd polírozzuk fel, lehetőleg kemény vászon polírozókendőt és gyémántszuszpenziót használva. A legfinomabb szuszpenzió 1 um-es legyen, ugyanis az ennél kisebb szemcseméretú szuszpenzió használata befolyásolhatja a szenes anyag szemcsék Raman-spektrumát (LÜNSDORF 2016).

- A lehető legrövidebb hullámhosszú (kék vagy UV) lézert használjuk a Raman-mérések során, ezáltal csökkentve a szenes anyag fluoreszcenciája okozta háttéremelkedést, valamint növelve a kevésbé érett szenes anyag szemcsék Raman-sávjainak intenzitását.

- Igen kisfokú metamorfózison átesett szenes anyag elemzésekor elsősorban a vitrinitet válasszuk (TAYLOR et al. 1998).

- A szemcsék kiválasztása során kerüljük a mintában található erôsen nyírt zónákat.

- Legalább 30, de ha lehetséges, 50 szemcsét elemezzünk egy mintából (AoYA et al. 2010).

- A lézer teljesítménye a minta felszínén ne haladja meg a 0,1 mW-ot, így elkerülhetjük a szenes anyag szemcsék termális átalakulását a mérések során.

- A minél jobb háttérillesztés érdekében lehetőleg 400 és $2200 \mathrm{~cm}^{-1}$ között vegyük fel a szenes anyag spektrumát.

- Az adatfeldolgozást az IFORS szoftverrel végezzük (LÜNSDORF \& LÜNSDORF 2016), így kiküszöbölhetjük az operátor által manuálisan feldolgozott spektrumok okozta bizonytalanságot, valamint használni tudjuk az ajánlott termométert. A szoftver ingyenesen letölthető a http://www. sediment.uni-goettingen.de/download/ weboldalról.

- A publikációban mindig dokumentáljuk, milyen paraméterekkel használtuk az IFORS szoftvert (1. Digitális melléklet).

- Ha a Raman-spektrumon a szenes anyagon kívül más fázis is jelen van (pl. ha átlátszó ásványban lévő vagy az alatti szemcsét mérünk), akkor ezek Raman-sávjait vonjuk le a kiértékelés előtt, erre az IFORS-ban van lehetôség.

\section{A szenes anyag Raman-spektroszkópián alapuló STA-RSCM termométer bemutatása}

A vitrinit fó prekurzora a lignin (HATCHER 1990, HATCHER \& CLIFFORD 1997), amely a szénült üledékek legfőbb aromás szénhidrogén komponense (HATCHER 1990). Az érés során a szerves anyag elveszíti oxigéntartalmú funkciós csoportjait (karbonsavak, szén-dioxid és víz) és a hosz-szú szénláncú szerves molekulák depolimerizálódnak. A depolimerizáció során, OBERLIN \& BONNAMY (2013) modellje alapján a szerves anyag olyan szuszpenziót alkot, amiben a nehezebb molekuláris alegységek (basic structural units; BSU - elemi szerkezeti egységek) úsznak a könnyebb molekulaegységek között. Ezek az elemi szerkezeti egységek 2-3 policiklikus aromás szénhidrogénból ( $\mathrm{PAH}$ - polycyclic aromatic hydrocarbon) állnak össze. A leggyakrabban használt modellek szerint a PAH-ok grafitos alegységekből, szigetekből épülnek fel, amelynek Raman-spektruma folyamatos változást mutat az érés során (OBERLIN \& BonnAmy 1989, 2013; OBERLin et al. 1999). A grafit Raman-sávjai két régióban jelennek meg (pl. WoPENKA \& PASTERIS 1993; BEYSSAC \& LAZZERI 2012). Az úgynevezett elsőrendú régióban $\left(\sim 2000 \mathrm{~cm}^{-1}\right.$ alatti Raman-eltolódás) két fő sáv található, $\sim 1582$ és $\sim 1350 \mathrm{~cm}^{-1}$-nél. Előbbi az úgynevezett G (grafit) sáv, míg utóbbi az ún. D1 (disordered - rendezetlen) sáv elnevezéssel jelenik meg a szakirodalomban (1. ábra). Tökéletesen kristályos grafit esetén csak a G-sáv azonosítható, míg a D1-sáv csak a rendezetlenebb szerkezettel rendelkezô szenes anyagban jellemző. Nem tökéletesen kristályos grafit esetén további rendezetlen sávok is megjelenhetnek az elsôrendû régióban. A D2-sáv a D1-hez hasonlóan a szerkezeti rendezetlenség eredményeképp jelenhet meg a G-sáv vállán, 1620 cm-1-nél (PIMENTA et al. 2007). Az amorf szén jellegzetes sávja, a D3-sáv 1500 cm-1-nél látható (1. ábra; BENY-BASSEZ \& RoZAUD 1985). A D1-sáv vállán, 1180 és $1250 \mathrm{~cm}^{-1}$ között megjelenô D4-sáv pedig a grafitrétegekből kilógó tetraéderes szénatomok rezgéseiből származtatható (1. ábra; SADEZKY et al. 2005; LAHFID et al. 

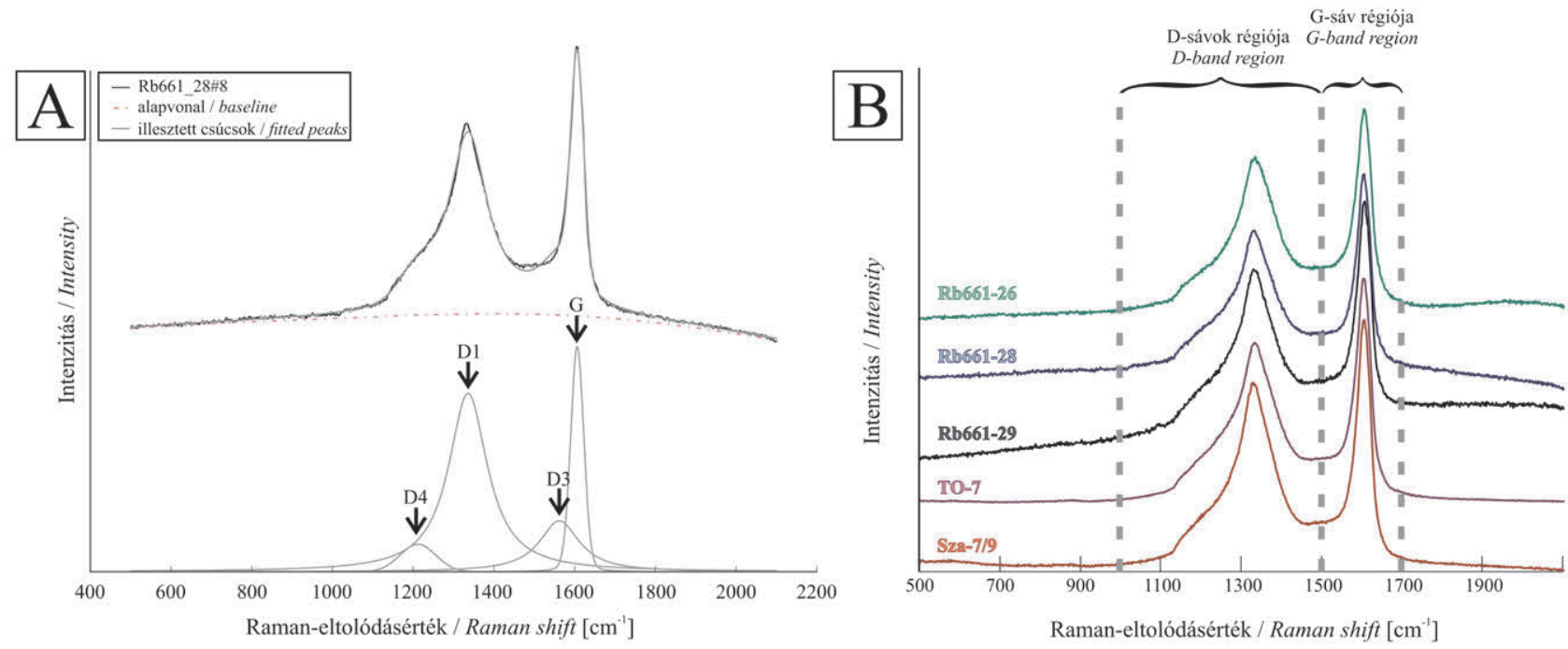

1. ábra. Szenes anyag szemcsék (vitrinit) Raman-spektrumai az esettanulmány során vizsgált kőzetsorozatban.

A, Vitrinit jellegzetes Raman-spektruma és a ráillesztett csúcsok (D1, D3, D4 és G) az egyik vizsgált mintából (Rb-661_28). B, Vitrinitszemcsék Raman-spektrumai a vizsgált kőzetekből

Figure 1. Raman spectra of the carbonaceous materials (vitrinite) in the studied samples.

A, Characteristic spectra and bands (DI, D3, D4 and G) of vitrinite from a studied sample (Rb-661_28). B, Raman spectra of vitrinite from the studied samples

2010). Az érettség csökkenésével a G-sáv pozíciója fokozatosan változik $\sim 1582 \mathrm{~cm}^{-1}$-rôl $\sim 1610 \mathrm{~cm}^{-1}$-ig és aszimmetrikus lesz (LAHFID et al. 2010). Ezzel párhuzamosan a D1sáv felhasad, egy 1330 és egy $1380 \mathrm{~cm}^{-1}$-nél elhelyezkedő sávra (LiU et al. 2013) oszlik.

A korábbi munkákban ezen sávok csúcspozíciójának változásai vagy a sávok félértékszélességei alapján becsülték meg a szenes anyag érési hőmérsékletét (pl. BEYsSAC et al. 2002, RAHL et al. 2005, KouKETSU et al. 2014), azonban LÜNSDORF \& LÜNSDORF (2016) munkája bemutatta, hogy ezeknek a paramétereknek a használata nem minden esetben alkalmas a hômérséklet pontos meghatározására. Ezekkel szemben az ajánlott paraméter, amely folyamatos változást mutat mind a szénülés, mind a grafitosodás során (100 és $600{ }^{\circ} \mathrm{C}$ között), az a D-, illetve a G-sávokra arányosított csúcs alatti terület (D_STA és G_STA; scaled total area; LÜNSDORF \& LÜNSDORF 2016; LÜNSDORF et al. 2017). A LÜNSDORF et al. (2017) által, ismert metamorf csúcshőmérsékletû referencia kőzetsorozaton elvégzett mérések azt mutatták, hogy a kisebb hőmérsékleti tartományban $\left(<300{ }^{\circ} \mathrm{C}\right)$ a D_STA értékek fokozatosan csökkennek a növekvő hőmérséklettel. Ezzel szemben a G_STA értékek csak kb. $270{ }^{\circ} \mathrm{C}$-ig mutatták ugyanezt a tendenciát, e felett pedig fokozatosan növekvő értékek jelentkeztek. A nagyobb hőmérsékleti tartományban $\left(>300{ }^{\circ} \mathrm{C}\right)$ a D_STA értékek $\sim 400{ }^{\circ} \mathrm{C}$-ig tartották a csökkenô trendet, míg e felett fokozatosan növekedtek. Ezzel szemben a G_STA értékek kb. $370{ }^{\circ} \mathrm{C}$-ig konstansnak mutatkoztak, ezt követően pedig exponenciális csökkenés volt tapasztalható. Ezt a $400{ }^{\circ} \mathrm{C}$ körüli hőmérsékleti tartományt, ahol a D-, illetve a G-sávokra arányosított csúcs alatti területek tendenciájában változás következik be, átmeneti zónának nevezték el (LÜNSDORF et al. 2017). Munkájukban LÜNSDORF et al. (2017) bevezettek egy úgynevezett G-alaktényezőt, amely az $1575 \mathrm{~cm}^{-1}$ és 1590 $\mathrm{cm}^{-1} \mathrm{~cm}$ közötti Raman-eltolódáshoz tartozó átlagos intenzitásnak és az 1610 és 1630 közötti Raman-eltolódáshoz tartozó átlagos intenzitásnak az aránya. Ez a tényező jellemzi a G-csúcs (1. ábra) alakjának alakulását a hőmérséklet függvényében. Megfigyelték, hogy kisebb hőmérsékleti tartományban $\left(<300^{\circ} \mathrm{C}\right)$ ez az érték 1 körül mozog, míg a 350-400 ${ }^{\circ} \mathrm{C}$-os tartománytól exponenciális emelkedést mutat (I. táblázat). A határértéket 3-nál állapították meg a G-alaktényezőre vonatkozóan, az ennél kisebb értékeknél a D_STA, míg az ennél nagyobbnál a G_STA érték használandó a hőmérséklet meghatározásához. Így a G-alaktényező lehetőséget nyújt a két, önmagukban váltakozó tendenciát mutató csúcs alatti terület összekapcsolására és egy folytonos trend kirajzolására, amelyben a D-, illetve a G-csúcsra arányosított csúcs alatti területek folyamatos csökkenést mutatnak a hőmérséklet emelkedésének függvényében (2. ábra).

\section{A referencia kózetsorozat}

A kalibrációs görbe elkészítéséhez használt kőzetsorozat mintáinak részletes leírása LÜNSDORF et al. (2017) munkájában található. A referencia kőzetsorozat egy-egy darabját Dr. Keno LÜNSDORF bocsátotta rendelkezésünkre. A kőzetsorozat mintái a Nyugati-Alpokból származnak, független módszerrel (pl.: klorit termométer, kalcit-dolomit termométer) meghatározott metamorf csúcshőmérséklettel rendelkeznek, és a mély diagenezis - nagyfokú metamorfózis hőmérséklettartományát fedik le (kb. 160-600 C; I. táblázat).

A referenciasorozat mintáit a LÜNSDORF et al. (2017) által javasolt protokoll szerint készítettük elő. A $300{ }^{\circ} \mathrm{C}$-nál kisebb metamorf csúcshőmérsékletû mintákból beágyazott 
I. táblázat. A referencia kőzetsorozat metamorf csúcshőmérsékletei (LÜNSDORF et al. 2017), valamint az ELTE TTK KKIC Raman-laboratóriumában végzett mérések eredményei (D_STA, G_STA és G-alaktényező, valamint ezek szórásai), amelyek a kalibrációs görbe (2. ábra) alapját szolgálják

Table I. Metamorphic peak temperatures of the reference series samples (LÜNSDORF et al. 2017), and the computed D_STA, G_STA and $G$-shape factors with their uncertainties at the ELTE TTK KKIC Raman laboratory. These values were used to compute the calibration curve (Figure 2)

\begin{tabular}{|c|c|c|c|c|c|c|c|c|c|}
\hline Referenciaminta* & $\begin{array}{c}\text { Metamorf } \\
\text { csúcshőmérséklet } \\
{\left[{ }^{\circ} \mathrm{C}\right]}\end{array}$ & D_STA & std & G_STA & std & G-alaktényező & std & $\mathrm{n}$ & STA $_{532}$ \\
\hline KL14-5_elte & $162 \pm 30$ & 238 & 10 & 157 & 8 & 1,24 & 0,11 & 15 & 238 \\
\hline KL14-7_elte & $178 \pm 30$ & 220 & 18 & 150 & 15 & 0,99 & 0,08 & 16 & 220 \\
\hline KL14-21_elte & $228 \pm 30$ & 198 & 19 & 118 & 13 & 0,88 & 0,15 & 13 & 199 \\
\hline KL14-16_elte & $236 \pm 30$ & 210 & 22 & 124 & 17 & 0,99 & 0,19 & 30 & 210 \\
\hline KL16-31_elte & $236 \pm 30$ & 188 & 20 & 108 & 12 & 0,69 & 0,04 & 23 & 188 \\
\hline KL16-35_elte & $240 \pm 30$ & 203 & 10 & 128 & 12 & 0,86 & 0,06 & 20 & 203 \\
\hline KL14-17_elte & $256 \pm 30$ & 177 & 6 & 109 & 3 & 0,93 & 0,05 & 20 & 177 \\
\hline KL16-43_elte & $262 \pm 30$ & 183 & 8 & 113 & 6 & 1,04 & 0,06 & 14 & 183 \\
\hline KL14-13_elte & $267 \pm 30$ & 173 & 8 & 108 & 6 & 0,83 & 0,15 & 13 & 173 \\
\hline KL14-1_elte & $295 \pm 25$ & 120 & 14 & 117 & 17 & 0,80 & 0,05 & 24 & 120 \\
\hline KL14-19_elte & $299 \pm 23$ & 154 & 2 & 120 & 2 & 0,79 & 0,02 & 20 & 154 \\
\hline KL16-8_elte & $325 \pm 25$ & 128 & 11 & 134 & 8 & 0,76 & 0,03 & 23 & 128 \\
\hline KL16-19_elte & $350 \pm 25$ & 81 & 6 & 157 & 10 & 1,09 & 0,04 & 10 & 81 \\
\hline KL14-58_elte & $370 \pm 50$ & 73 & 8 & 150 & 21 & 1,18 & 0,20 & 25 & 73 \\
\hline KL16-10_elte & $375 \pm 35$ & 73 & 7 & 162 & 18 & 1,26 & 0,05 & 20 & 73 \\
\hline KL16-11_elte & $375 \pm 35$ & 77 & 5 & 140 & 10 & 1,33 & 0,15 & 23 & 77 \\
\hline KL16-14_elte & $415 \pm 35$ & 78 & 7 & 88 & 12 & 2,34 & 0,45 & 20 & 78 \\
\hline KL14-59_elte & $420 \pm 50$ & 68 & 5 & 87 & 6 & 2,62 & 0,13 & 15 & 68 \\
\hline KL16-29_elte & $420 \pm 30$ & 74 & 13 & 66 & 8 & 3,36 & 0,28 & 20 & 66 \\
\hline KL16-27_elte & $440 \pm 30$ & 79 & 12 & 53 & 7 & 4,56 & 0,79 & 9 & 53 \\
\hline KL14-56_elte & $450 \pm 30$ & 70 & 8 & 59 & 7 & 3,96 & 0,48 & 12 & 59 \\
\hline KL16-23_elte & $480 \pm 40$ & 102 & 17 & 40 & 5 & 6,58 & 2,33 & 25 & 40 \\
\hline KL16-15_elte & $490 \pm 40$ & 86 & 14 & 45 & 6 & 4,58 & 1,15 & 23 & 45 \\
\hline KL16-16_elte & $490 \pm 40$ & 102 & 37 & 41 & 11 & 6,50 & 2,71 & 17 & 41 \\
\hline KL14-52_elte & $520 \pm 25$ & 132 & 51 & 36 & 10 & 9,37 & 3,17 & 21 & 36 \\
\hline
\end{tabular}

*A referenciaminták részletes adatsorát LÜNSDORF és munkatársai (2017) cikke tartalmazza.

blokkok, felületi csiszolatok, míg a $300^{\circ} \mathrm{C}-n a ́ l$ nagyobb hőmérsékletúekből vékonycsiszolatok készültek. A minták felpolírozása során használt legfinomabb szuszpenzió 1 $\mu$ m-es volt a protokollnak megfelelően (LÜNSDORF 2016).

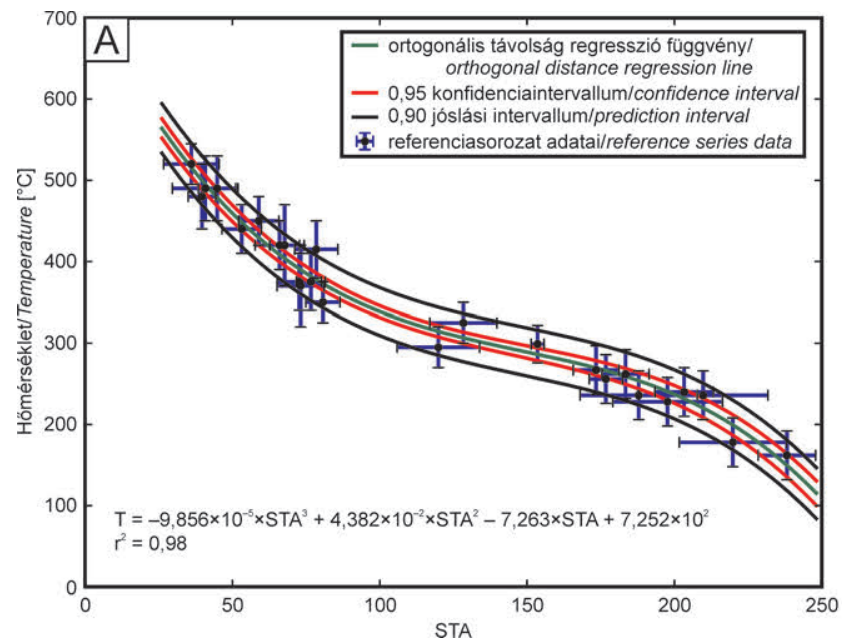

\section{Mérési körülmények}

A Raman-mikrospektroszkópos méréseket az Eötvös Loránd Tudományegyetem Természettudományi Karán múködő Központi Kutató és Ipari Kapcsolatok Centrum

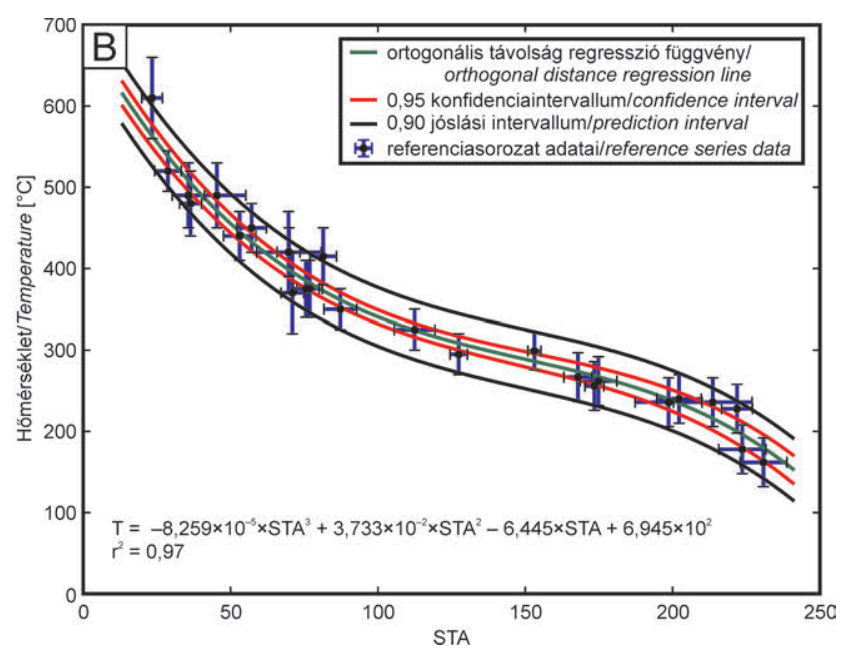

2. ábra. Az ELTE-KKIC Raman-laboratóriumában mért referencia mintasorozat kalibrációs görbéje (A) összevetve a LÜNSDORF et al. (2017) által publikált görbével (B) Figure 2. The calibration curves of the reference sample series measured in the ELTE-KKIC Raman laboratory (A) and reported in LÜNSDORF et al. (2017) (B) 
(KKIC) Horiba Jobin Yvon gyártmányú LabRAM HR800 típusú konfokális Raman-mikrospektrométerén végeztük. Gerjesztő fényforrásként 532 nm-es hullámhosszú (zöld) Nd:YAG lézert használtunk. A lézer névleges teljesítménye a forrásnál $130 \mathrm{~mW}$, a minta felszínére ezt szúrők segítségével 0,2 mW-ra csökkentettük, elkerülve a szenes anyag foto-oxidációját, illetve termális átalakulását a lézersugár hatására. A lézert egy Olympus BXFM mikroszkóp 100x-os nagyítású, 0,9-es numerikus apertúrájú objektívével fókuszáltuk a minta felszínére, a konfokális rés $100 \mu \mathrm{m}$ volt. Az adatgyújtési idő 2-4×10-30 másodperc volt, a spektrumok 500 és $2100 \mathrm{~cm}^{-1}$ között lettek rögzítve. A mérések során 600 barázda (grooves)/mm felbontású optikai rácsot használtunk.

Mintánként 15-30 szenes anyag szemcsét elemeztünk (az adott mintában rendelkezésre álló szenes anyag szemcsék mennyiségének függvényében), a vékonycsiszolatok esetében a színtelen, jellemzően kalcit szemcsékben/alatt lévő szenes anyag szemcséket választottuk ki a mérésre
(BEYSSAC et al. 2002, LÜNSDORF et al. 2017). A háttér- és csúcsillesztést a LÜNSDORF \& LÜNSDORF (2016) által bemutatott IFORS szoftver segítségével végeztük. A kalibrációs görbe létrehozása szintén ezzel a szoftverrel történt, a vizsgált referenciaminták spektrumainak csúcs alatti területei, valamint a független módszerrel meghatározott metamorf csúcshőmérséklet alapján (I. táblázat). Az általunk létrehozott, illetve a LÜNSDORF et al. (2017) által közölt kalibrációs görbéket a 2. ábra mutatja be. A mért referencia kőzetsorozat részletes adatsorait (D(STA), G(STA), G-alaktényező, $\mathrm{D}_{\max }$-pozíció, $\mathrm{G}_{\max }$-pozíció és $\mathrm{D}_{\max } / \mathrm{G}_{\max }$ arányértékek) az $I$. táblázat tartalmazza. A LÜNSDORF et al. (2017) által megfigyelt tendenciák - a csúcs alatti területek (D(STA), G(STA)) és a G-alaktényezó változása a metamorf csúcshőmérséklet növekedésének függvényében - az általunk elvégzett méréseken is jól nyomon követhetôk (I. táblázat). Az ELTE TTK KKIC Raman-laboratóriumában létrehozott kalibrációs görbe egyenlete (2. ábra; LÜNSDORF et al. 2017 alapján):

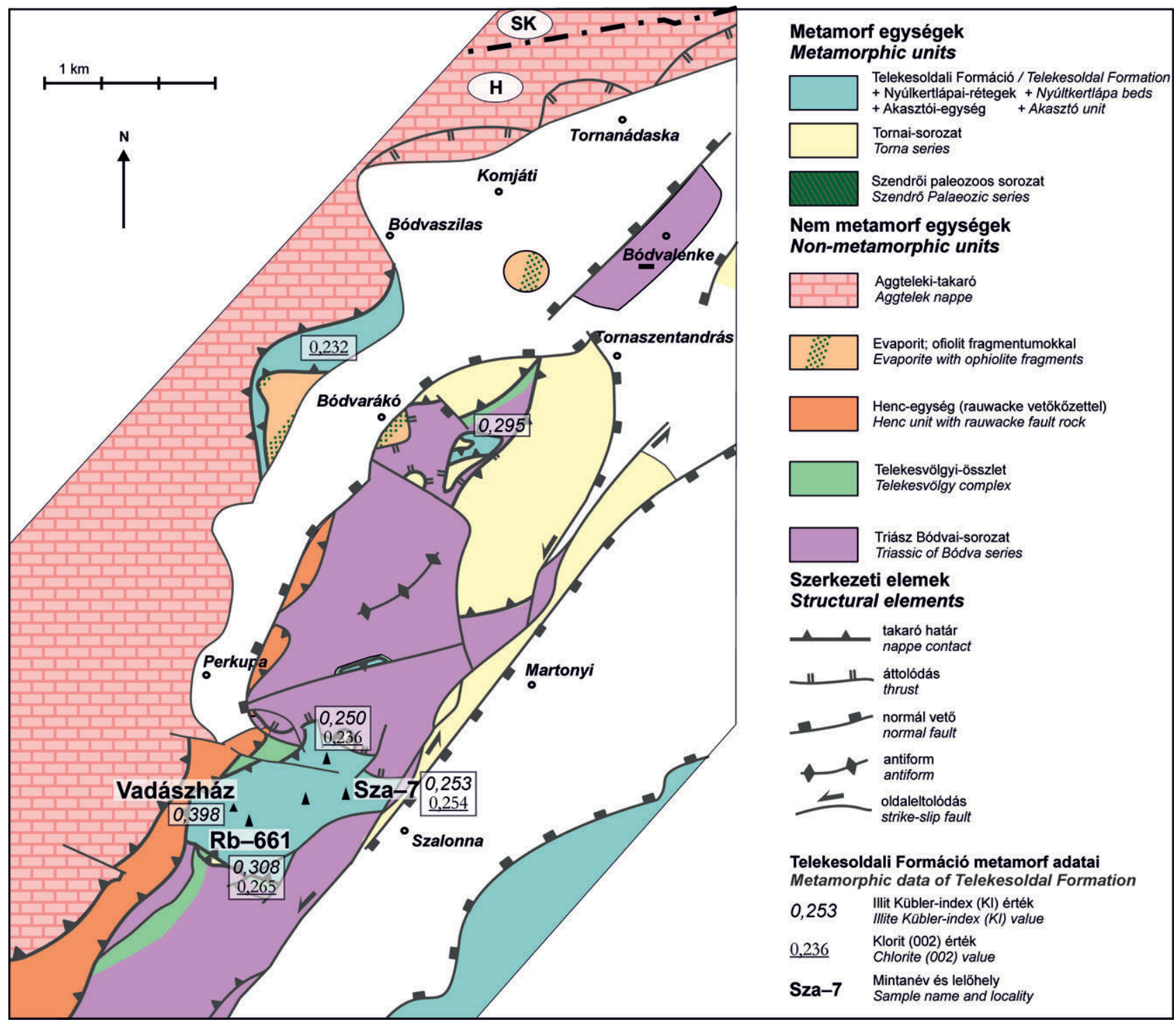

3. ábra. A terület egyszerüsített földtani térképe (KovÁCs 1989, KoROKNAI 2004, KöVÉR et al. 2009a, DEÁK-KövÉR 2012 alapján)

Figure 3. Simplified geological map of the studied area (after KoVÁCS 1989, KOROKNAI 2004, KÖVÉR et al. 2009a, DEÁK-KÖVÉR 2012) 


\section{$\mathrm{T}_{532 \mathrm{~nm}}\left({ }^{\circ} \mathrm{C}\right)=-9,856 \times 10^{-5} \times \mathrm{STA}^{3}+4,382 \times 10^{-2} \times \mathrm{STA}^{2}-$ $7,263 \times \mathrm{STA}+7,252 \times 10^{2}$}

ahol az STA a D-csúcsra (ha G-alaktényezô <3), illetve a Gcsúcsra (ha G-alaktényező > 3) vonatkoztatott csúcs alatti területnek felel meg. Ez az egyenlet, valamint a kalibrációs görbe lefutása laborról laborra változik a referenciasorozaton alapuló mérések, a használt lézer hullámhossza, valamint a Raman-spektrométer egyedi beállításainak függvényében (2. ábra). Mivel a referenciasorozatra meghatározott metamorf csúcshőmérsékletek rögzítettnek tekinthetők, ezáltal az egyes laborok egyedi kalibrációs görbéi alapján született eredmények összehasonlíthatóvá válnak.

\section{Esettanulmány (Aggtelek-Rudabányai-hegység)}

Az Aggtelek-Rudabányai-hegység a Belső NyugatiKárpátok része, késô perm-jura korú üledékes kőzetek építik fel (BALOGH \& PANTó 1949, 1952; LESS et al. 1988; SZENTPÉTERY \& LESS 2006). Az esettanulmány során vizsgált minták a középsô, késő jura Telekesoldali Formációból származnak (3. ábra).

\section{Telekesoldali Formáció (TO)}

Az összletet agyagpala, finom- és aprószemcsés homokkőrétegek és boudinek, valamint polimikt olisztosztrómarétegek alkotják, kevés korjelző ősmaradvánnyal (GRILL 1988). Az összlet kora a szegényes radioláriafauna és dinoflagelláta ciszták alapján kora bajoci-kallovi (KöVÉR et al. 2009b, DEÁK-KÖvÉR 2012), bár GRILL (1988, 2012) úgy véli, hogy a képződés a késô jurába is felnyúlik.

A vizsgált minták az összlet tipikus litofácieséből származnak, ami sötétszürke-fekete agyagpala és márgapala, amelyben kvarcerek, illetve vékony, finomszemcsés homokrétegek fordulnak elő, képlékeny deformációra utaló jelekkel. A homokkőben a domináns kvarcszemcsék mellett jelentôs mennyiségú plagioklász és változó mennyiségú muszkovit fordul elő (KÖvÉR et al. 2008, 2009b).

Munkánk során a Rudabánya Rb-661 és a Szalonna Sza7 fúrásból származó mintákat, valamint egy felszíni mintát (Telekesoldal, Vadászház - TO-7) vizsgáltunk (3. ábra; II. táblázat). Itt sötétszürke agyag és márgapala érintkezik egy több tíz méteres riolit olisztolittal, amelynek kora 219,3 \pm 6,2 millió év (KövÉR et al. 2018).

Az Sza-7 jelú fúrás a Nagy Telekes-tetô ÉK-i oldalán mélyült, és végig a Telekesoldali Formációba sorolható fekete és sötétszürke agyagpalát, aleuritpalát, márgapalát harántolt (KövÉR et al. 2008). A vizsgált Sza-7/9 minta 181,5 m-rôl származik, ami fekete agyagpala sûrú palássággal, gyürt kalciterekkel.

Az Rb-661 fúrás felső részét a Telekesoldali Formációba sorolható agyagpala és riolit olisztolit alkotja (4. ábra), ami egy 10 m vastag tektonikus breccsa mentén érintkezik az alatta található anhidritrétegeket és gipszereket tartalmazó, tarka sziliciklasztos-dolomitos sorozattal (felsô perm Perkupai Evaporit Formáció). A minták számát, helyzetét a 3. és 4. ábrák mutatják be.

\section{Petrográfiai leírás}

Agyagkő, metaaleurolit, agyagmárga és márga a leggyakrabban előforduló kőzettípusok az összletben. A fő kőzetalkotó kvarc mellett illit-K-fehér csillám, klorit, kalcit, dolomit (Sza-7, Rb-661) és plagioklász (albit) jelenik meg számottevő mennyiségben (Sza-7), járulékos elegyrészkén pedig pirit, rutil (Sza-7, Rb-661), spinell (Sza-7, TO-7) és hematit (Sza-7) fordulhat elő a vizsgált mintákban (DEÁKKÖVÉR 2012). Az Rb-661 fúrás legalsó része jelentős menynyiségú gipszet is tartalmaz (DEÁK-KövÉR 2012).

A legtöbb szenes anyag (vitrinit) szemcse a szemcseközi térben helyezkedik el, más típusú szerves anyag szemcsék (5. ábra $A-B$ ), valamint a kőzetalkotó kvarc- és kalcitszemcséi között (5. ábra $C-D)$ fordulnak elő. A vitrinitszemcsék alakja izometrikus (5. ábra $C-D)$, bizonyos esetekben a palássággal párhuzamosan megnyúltak (5. ábra $E-F)$. Maxi-

II. táblázat. A vizsgált Telekesoldali minták Raman-adatsora (D_STA, G_STA és G-alaktényező, valamint ezek szórásai) és a számolt metamorf csúcshőmérsékletek

Table II. Raman data (D_STA, G_STA and G-shape factor with their uncertainties) of the studied Telekesoldal samples and the computed metamorphic peak temperatures

\begin{tabular}{|c|c|c|c|c|c|c|c|c|c|c|c|}
\hline Mintanév & Lelöhely & Közettipus & $\begin{array}{c}\text { Metamorf } \\
\text { csúcshőmérséklet } \\
{\left[{ }^{\circ} \mathrm{C}\right]^{*}}\end{array}$ & D_STA & std & G_STA & std & G_alaktényező & std & $\mathrm{n}$ & $\mathrm{STA}_{532}$ \\
\hline $\begin{array}{l}\text { T0-7 } \\
\text { (felszíni } \\
\text { minta) }\end{array}$ & $\begin{array}{c}\text { Telekesoldal, } \\
\text { vadászház }\end{array}$ & $\begin{array}{c}\text { metaaleurolit- } \\
\text { agyagkö }\end{array}$ & $262 \pm 10$ & 180 & 10 & 129 & 10 & 0,87 & 0,10 & 29 & 180 \\
\hline $\begin{array}{c}\text { Rb661-28 } \\
(84,8 \mathrm{~m})\end{array}$ & $\begin{array}{l}\text { Rudabánya } \\
\text { 661-es fúrás }\end{array}$ & agyagmárga & $273 \pm 6$ & 169 & 6 & 116 & 5 & 0,81 & 0,04 & 32 & 169 \\
\hline $\begin{array}{l}\text { Rb661-26 } \\
(130,4 \mathrm{~m})\end{array}$ & $\begin{array}{l}\text { Rudabánya } \\
\text { 661-es fúrás }\end{array}$ & márga & $274 \pm 8$ & 167 & 10 & 117 & 9 & 0,79 & 0,08 & 33 & 167 \\
\hline $\begin{array}{c}\text { Rb661-29 } \\
(65 \mathrm{~m})\end{array}$ & $\begin{array}{l}\text { Rudabánya } \\
\text { 661-es fúrás }\end{array}$ & $\begin{array}{c}\text { márga- } \\
\text { agyagmárga }\end{array}$ & $276 \pm 8$ & 165 & 10 & 115 & 12 & 0,81 & 0,04 & 31 & 165 \\
\hline $\begin{array}{c}\mathrm{Sza} 7 / 9 \\
(181,5 \mathrm{~m})\end{array}$ & $\begin{array}{l}\text { Szalonna } 7 \text {-es } \\
\text { fúrás }\end{array}$ & agyagkő & $280 \pm 8$ & 164 & 6 & 118 & 10 & 0,80 & 0,04 & 32 & 164 \\
\hline
\end{tabular}




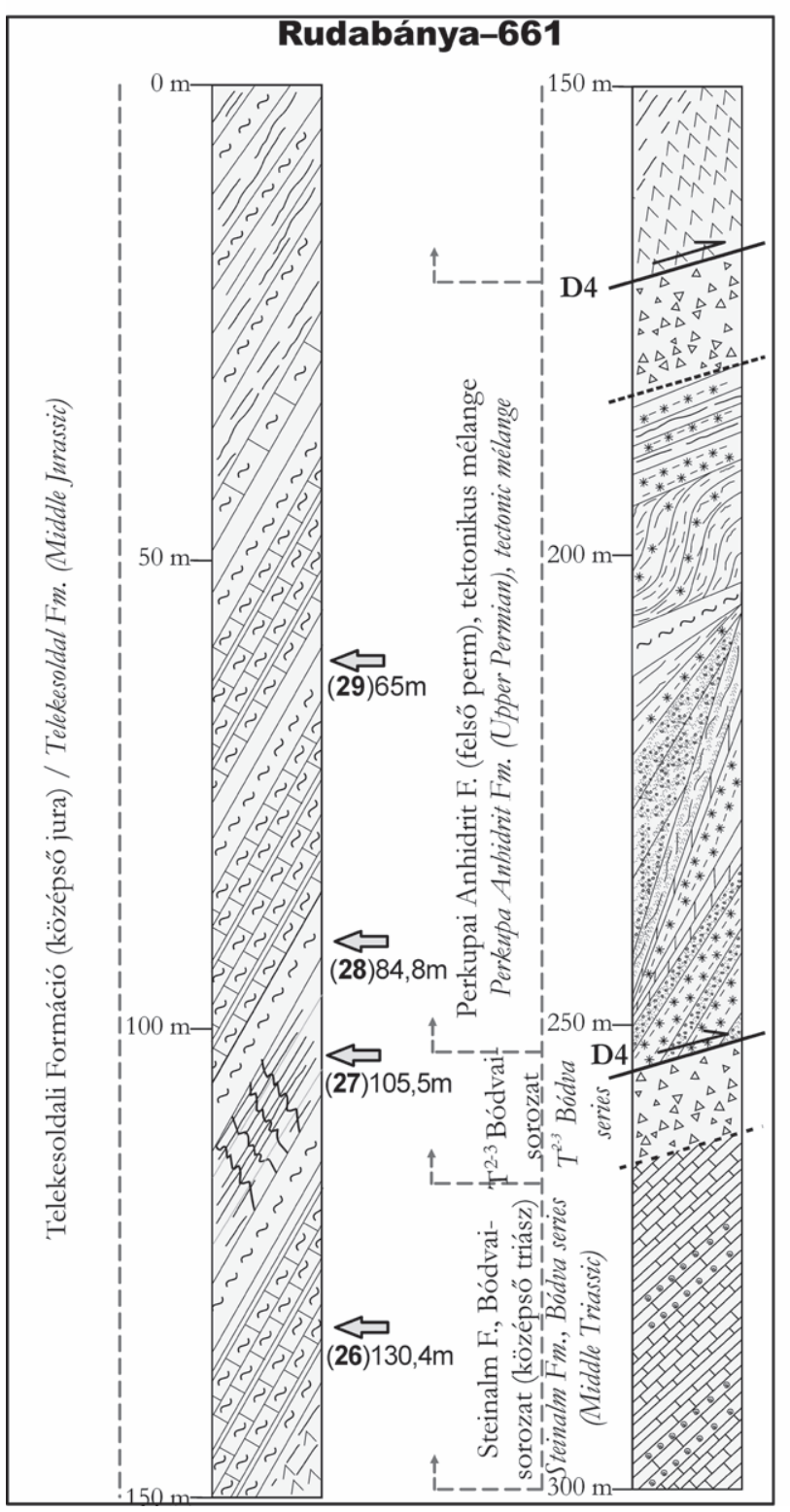

mális átmérőjük jellemzően 5-10 $\mu \mathrm{m}$, de a megnyúlt szemcsék akár az $50 \mu \mathrm{m}$-t is elérhetik (5. ábra $E-F$ ).

\section{Korábbi eredmények összefoglalása}

A Telekesoldali Formációt ért metamorf csúcshőmérsékletet a korábbi munkák illit (Kübler-index, KI) és klorit „kristályosság” (ChC), valamint vitrinit reflexió (VR) alapján próbálták becsülni (6. ábra). Ezek közül számszerú hőmérsékleti értéket csupán a vitrinit reflexióból lehet számolni, míg az illit és klorit „kristályossági” értékekből csak a metamorf tartományra (diagenetikus-anchizóna-epizóna) lehet következtetni. Az anchizóna határai 0,25-0,42 $\Delta^{\circ} 2 \Theta$ $\mathrm{KI}$, ahol a $0,25 \Delta^{\circ} 2 \Theta \mathrm{KI} \sim 300-350{ }^{\circ} \mathrm{C}$-nak, míg a 0,42 $\Delta^{\circ} 2 \Theta \mathrm{KI} \sim 200{ }^{\circ} \mathrm{C}$-nak feleltethető meg (6. ábra; ÁRKAI 1991). Az anchizónán belül elkülönítenek egy kis és egy nagy hőmérsékletű régiót, ennek határa $0,30 \Delta^{\circ} 2 \Theta \mathrm{KI}$ (ÁrKAI 1991). A teljes Telekesoldali Formációra meg-

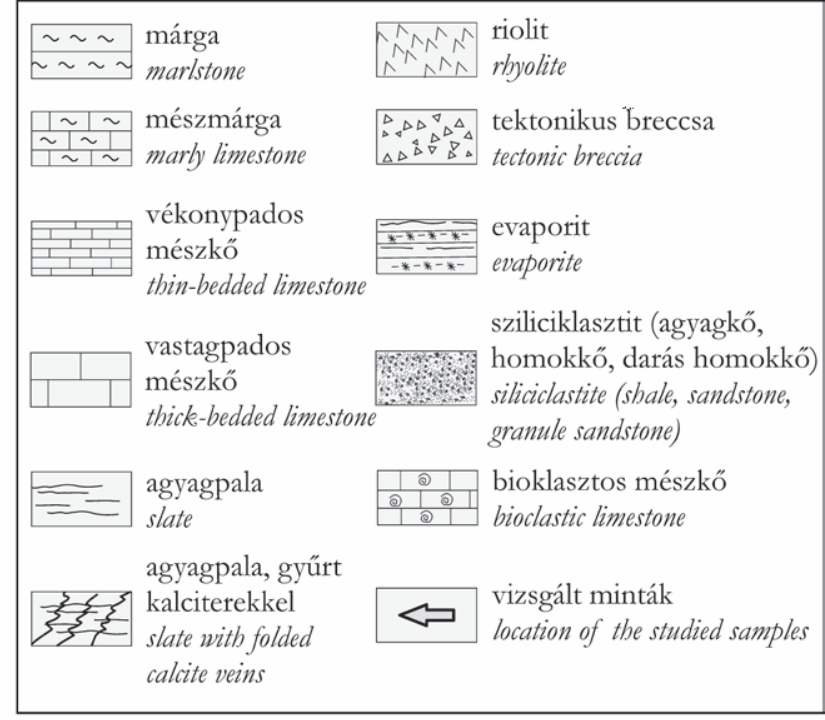

4. ábra. Rudabánya Rb-661 fúrás rekonstruált képe (DEÁK-KöVÉR 2012), a szürke nyilak jelzik a vizsgált minták fúráson belüli elhelyezkedését, valamint a minták kódját és méterközét. D4 az áttolódás szerkezeti kódja DEÁK-KöVÉR (2012) alapján

Figure 4. Reconstructed features of the Rb-661 borehole (DEÁK-KÖVÉR 2012). The grey arrows mark the locations, sample codes and depths of the studied samples. D4 is the structural code of the thrusting after DEÁK-KÖVÉR (2012)

határozott KI-értékek többségükben az anchizóna nagy hőmérsékletû régiójába estek: KI: 0,130-0,398 $\Delta^{\circ} 2 \Theta$,

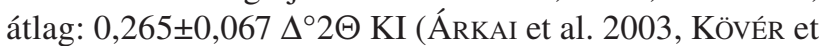
al. 2009a, DEÁK-KövÉr 2012). A vizsgált minták közül az Rb-661-es fúrásra meghatározott KI-értékek átlaga: 0,308 $\pm 0,045 \Delta^{\circ} 2 \Theta$, az Sza-7-es fúrásra 0,283 $\pm 0,006$ $\Delta^{\circ} 2 \Theta$, míg a felszíni mintára (TO) $0,398 \Delta^{\circ} 2 \Theta$ (DEÁKKÖvÉR 2012). Ezek kicsit kisebb hômérsékleti tartományt jeleznek, mint a teljes összletre meghatározott átlagérték. A két fúrásra meghatározott KI-értékek az anchizóna kis és nagy hőmérsékletú tartományának a határára esnek, míg a felszíni minta a kis hőmérsékletû anchizóna régióba esik. A klorit „kristályossági” értékek hasonló eredményeket adtak a teljes összletre és a vizsgált mintákra vonatkozóan is. A teljes Telekesoldali Formációra meghatározott ChC (002) értékek is az anchizóna tartományba estek $\left(0,24-0,30 \Delta^{\circ} 2 \Theta\right.$ ), átlaguk 0,252 $\pm 0,018 \Delta^{\circ} 2 \Theta$ (ÁRKAI et al. 2003, KövÉr et al. 2009a, DEÁK-KöVÉR 2012). 


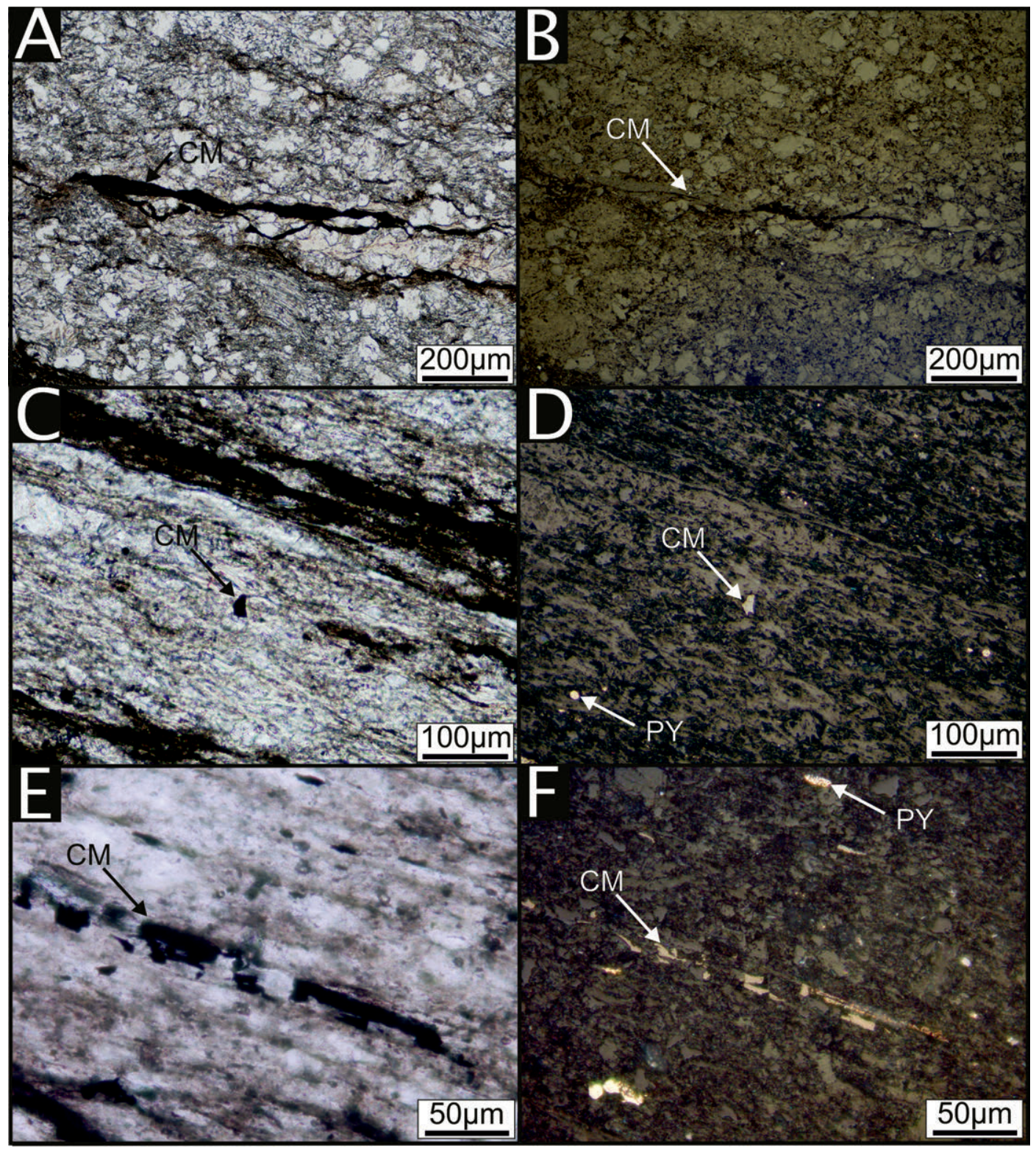

5. ábra. A vizsgált mintákban található szenes anyag szemcsék jellegzetes mikroszkópi képei (A, C, E: áteső fény, 1N; B, D, F: ráeső fény, $1 \mathrm{~N})$

A-B: Palássággal párhuzamosan megnyúlt, hullámos halmazokban megjelenő szerves anyag szemcsék az Rb-661-26 mintában. C-D: Izometrikus, szögletes vitrinit-szemcse föleg kalcitból álló mátrixban az Rb-661-28 mintában. E-F: Palássággal párhuzamosan megnyúlt, szögletes vitrinit-szemcsék a Rb-661-28 mintában. CM - szenes anyag; PY - pirit

Figure 5. Characteristic features of the vitrinite grains in the studied samples (A, C, E: transmitted light, $1 N$; B, D, E: reflected light, $1 N)$ $A-B$ : sample Rb-661-26; sheared particles occurring in undulating patches, parallel to the foliation. $C-D$ : sample Rb-661-28; isometric, rectangular vitrinite particle in the calcite matrix. E-F: sample Rb-661-28; isometric, but sheared vitrinite particles, parallel to the foliation. CM - carbonaceous material; PY - pyrite

Ezzel átfednek az Rb-661-es és az Sza-7-es fúrásra meghatározott értékek is $\left(0,243 \pm 0,019 \Delta^{\circ} 2 \Theta\right.$, illetve $\left.0,254 \pm 0,031 \Delta^{\circ} 2 \Theta\right)$, míg a felszíni minta kicsivel nagyobb értéket adott eredményül $\left(0,316 \quad \Delta^{\circ} 2 \Theta ;\right.$ DEÁK-KÖVÉR 2012). A maximum vitrinit reflexiós értékekből $\left(\mathrm{R}_{\max }: 4,8-\right.$ 5,6\%; ÁrKAI \& KovÁCS 1986, KÖVÉR et al. 2009a), BARKER (1988) egyenlete alapján, $\mathrm{R}=4,86 \%$-os átlaggal számolva a Telekesoldali Formációra kb. $310{ }^{\circ} \mathrm{C}$ metamorf csúcshőmérséklet adható meg. Ez jó egyezést mutat a kapott KI- és ChC-értékekből becsülhető hőmérsékletekkel (KövÉR et al. 2009a, DEÁK-KövÉr 2012).
Szenes anyag szemcsék Raman-spektroszkópiai vizsgálatán alapuló metamorf csúcshómérséklet meghatározás

Mintánként 29-33 vitrinit-szemcsét mértünk meg, ezek egy-egy jellegzetes spektrumát az 1. ábra, részletes adatait és Raman-spektrumait a II. táblázat, valamint a Digitális melléklet tartalmazza. A metamorf csúcshőmérsékleteket a referencia kőzetsorozaton alapuló kalibrációs görbe alapján határoztuk meg (2. ábra A). A mintákra kapott hőmérsékletek összesítve 242 és $301{ }^{\circ} \mathrm{C}$ között változnak. A nagyobb 


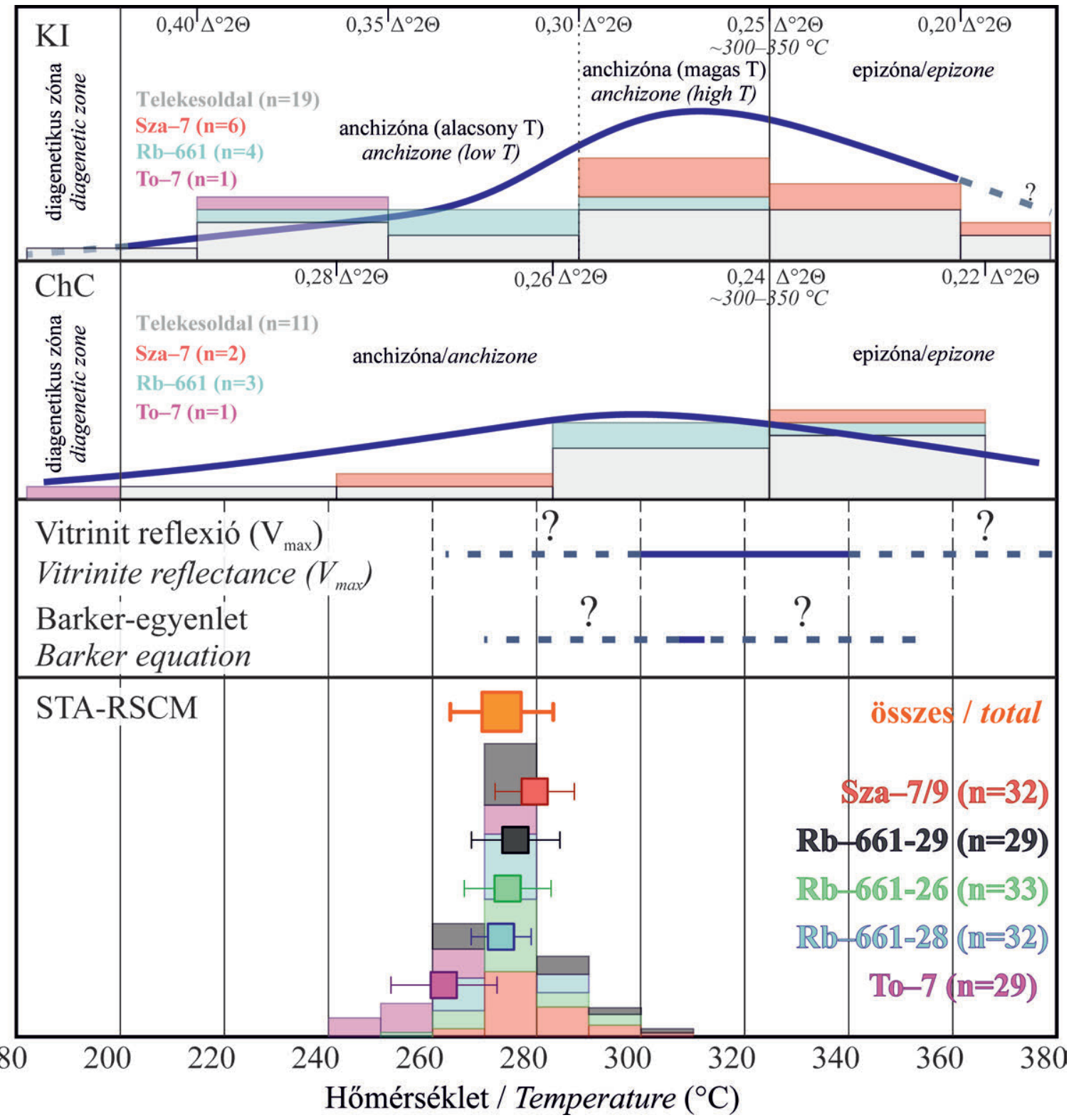

6. ábra. A szenes anyag szemcsék Raman-spektrumából számolt metamorf csúcshőmérsékletek eloszlása a tanulmányozott mintákban (STA-RSCM panel), valamint a korábbi eredményekböl becsülhető eredmények a Telekesoldali Formációra (KI, ChC és $\mathrm{V}_{\max }$ panelek; ÁRKAI et al. 2003 és DEÁKKÖVÉR 2012 alapján). A vitrinit reflexióból számolt, valamint az illit (KI) és klorit (ChC) „kristályosságból” becsülhető hőmérsékletek csak közelítő értékeket jeleznek, a kérdőjelek az adatok bizonytalanságát jelzik. Az anchizóna és epizóna határa 300-350 ${ }^{\circ} \mathrm{C}-\mathrm{ra}$ tehető (ÁRKAI 1991). Az STARSCM panelen szereplő hisztogram az egyedi vitrinitszemcsék mérési eredményein alapul, a kisebb négyzetek a vizsgált minták metamorf csúcshőmérsékleteinek az átlagát mutatják az adatok szórásaival együtt, míg a nagyobb négyzet az összesített metamorf csúcshőmérséklet-értéket $\left(273 \pm 10^{\circ} \mathrm{C}\right)$ jelöli. A KI, ChC és STA-RSCM paneleken az y tengely az adatok gyakoriságát mutatja be; $\mathrm{n}$ - mintaszám

Figure 6. Distribution of peak metamorphic temperatures calculated from the Raman spectra of vitrinite grains in the studied samples (STA-RSCM panel), and the previous results from the Telekesoldal Formation (KI, ChC and $V_{\max }$ panels based on data of ÁRKAI et al. 2003 and DEÁK-KöVÉR 2012). The estimated temperatures from the vitrinite reflectance, illite $(\mathrm{KI})$ and chlorite $(\mathrm{ChC})$ "crystallinity" data are approximations only, the question marks refer to the uncertainties of the values. Note the uncertainty of the anchizone-epizone temperature boundary ( 300-350 ${ }^{\circ} \mathrm{C}$; ARKAI 1991). The histogram on the STARSCM panel is based on the temperature data of the individual measured carbonaceous grains, the smaller rectangles are the average temperature results with uncertainties for each sample, whereas the larger rectangle is the averaged peak metamorphic temperature for the whole complex $\left(273 \pm 10{ }^{\circ} \mathrm{C}\right)$. The $y$ axis of the KI, ChC and STA-RSCM panels reflects on the frequency of the data; $n$ - number of measurements

metamorf csúcshőmérsékleteket a fúrásokból származó minták adták: az Sza-7-es fúrásból származó minta $280 \pm 8{ }^{\circ} \mathrm{C}$ ot, az Rb-661-es fúrásból származó 29 jelzésú minta $276 \pm$ $8{ }^{\circ} \mathrm{C}$-ot, a 26 jelzésú minta $274 \pm 8{ }^{\circ} \mathrm{C}$-ot, míg a 28 jelzésú minta $273 \pm 6^{\circ} \mathrm{C}$-ot adott eredményül (6. ábra). Ezzel szemben a felszíni Telekesoldal-mintából valamivel kisebb meta- morf csúcshőmérsékletet határoztunk meg $\left(262 \pm 10{ }^{\circ} \mathrm{C} ; 6\right.$. ábra). Az STA-RSCM termométer bizonytalansága a kalibrációs görbe illesztéséból adódóan $\pm 29{ }^{\circ} \mathrm{C}$, mivel azonban az egyes mintákra kapott értékek ennél kisebb tartományt fednek le, a bizonytalanságot a szórással (standard deviation) adtuk meg. A két fúrás, valamint a felszíni minta KI- 
értékeiben megjelenő minimális különbségek a meghatározott metamorf csúcshőmérsékleti értékekben is megfigyelhetốk (6. ábra; felszíni minta nagyobb KI-értéke, kisebb hômérséklete). Az egyes minták között megfigyelhetô minimális hőmérsékleti különbségek ellenére hibahatáron belül az összes kapott érték átfed egymással, egy $273 \pm 10^{\circ} \mathrm{C}$ metamorf csúcshómérsékleti tartományt jelölve ki a Telekesoldali Formáció tanulmányozott mintáira. A kapott hőmérsékleti adatok jó átfedést mutatnak a vizsgált mintákra korábban meghatározott hőmérséklet-tartománnyal (ÁRKAI et al. 2003, KöVÉR et al. 2009a, DEÁK-Kövér 2012). A vizsgált minták szenes anyag szemcséiből mért metamorf csúcshőmérsékletek átlagai $262-280^{\circ} \mathrm{C}$ közé esnek (6. ábra), amely megfeleltethetô az anchizóna nagy hőmérsékletû́ tartományának. Ezek az értékek egy szúkebb intervallumát adják a KI- és ChC-értékek alapján becsült tartománynak (6. ábra; DEÁK-KöVÉR 2012). A korábban a teljes összletre meghatározott vitrinit reflexióból a Barker-egyenlet (KövÉR et al. 2009a, DEÁK-KÖVÉR 2012) segítségével számolt hőmérséklet tartománya valamivel nagyobb metamorf hőmérsékletet jelölt ki $\left(310^{\circ} \mathrm{C}\right)$, azonban ez csak egy közelító módszer, amelynek bizonytalansága nem ismert, így az STA-RSCM termométer alapján számolt hőmérséklet tekinthető inkább elfogadhatónak.

\section{Következtetések}

A szenes anyag Raman-spektroszkópiai módszerrel meghatározott Raman-hőmérséklet értékek a 140 millió évvel ezelőtti kisfokú metamorfózis csúcshőmérsékletét rögzítik. A már rendelkezésre álló illit és klorit „kristályossági” értékek segítségével meghatározott hőmérsékleti tartományt (anchizóna nagy hőmérsékletú tartománya; DEÁKKöVÉR 2012) a jelen tanulmányban alkalmazott szenes anyag Raman-spektroszkópiai módszerrel sikerült leszúkíteni, pontosítani, így a Telekesoldali Formáció metamorf csúcshőmérséklete $273 \pm 10{ }^{\circ} \mathrm{C}$-ra tehető. A korábbi (illit és klorit „kristályosság”, illetve vitrinit reflexió) módszereken alapuló hômérséklet-meghatározások jóval szélesebb hômérsékleti tartományt fedtek le (6. ábra), nagyobb bizonytalansággal terheltek (vitrinit reflexió), illetve pontos hômérsékletértéket nem adnak minden esetben (Kübler-index, klorit „kristályosság), csak az összletek egymáshoz viszonyított helyzetére lehetett következtetni. Ezzel szemben az STA-RSCM termométer pontos hőmérséklet-meghatározást tesz lehetővé. Minden mért szenes anyag szemcséhez egy adott hőmérséklet rendelhetô (a hozzá tartozó bizonytalansággal együtt), így a módszer alkalmas egy képződményen, vagy adott esetben akár egy mintán belüli különbségek kimutatására is.

A bemutatott módszer szenes anyagot tartalmazó minták esetében jól alkalmazható a metamorf csúcshőmérséklet meghatározásához. További előnye, hogy a mérés elvégzése nem igényel bonyolult mintaelőkészítést, nem szükséges hozzá nagy mintamennyiség, jól egészíti ki az illit és klorit „kristályossági” módszereket, valamint a felületi- és vékonycsiszolaton belüli vizsgálat lehetővé teszi, hogy a kapott hőmérsékletértékekhez szöveti megfigyeléseket is társítsunk. Így ezek együttes alkalmazása hozzájárul egy adott terület metamorf fejlődéstörténetének a megismeréséhez. A jelen munka során az ELTE TTK KKIC Raman-laboratóriumában elkészített kalibrációs görbe lehetôvé teszi az ismeretlen hőmérsékletú minták meghatározását nemcsak a tanulmányban példaként bemutatott nagyon kisfokú - kisfokú metamorf tartományban, hanem jóval tágabb hőmérsékleti tartományban is $\left(160-600^{\circ} \mathrm{C}\right)$. Így akár érettebb szénhidrogének tároló és anyakőzetei vagy szenes összletek vizsgálatához is alkalmazható, kiváltva vagy kiegészítve a hagyományos vitrinit reflexiós méréseket.

\section{Köszönetnyilvánítás}

A szerzők köszönettel tartoznak Keno LÜNSDORFnak, hogy a referencia kőzetminta sorozatot a rendelkezésünkre bocsátotta.

A kutatást az Európai Unió és Magyarország támogatta az Európai Regionális Fejlesztési Alap társfinanszírozásában a GINOP-2.3.2-15-2016-00009 azonosítószámú 'IKER' pályázatban, valamint a K113013 számú NKFIHOTKA pályázatban.

ARADI László Előd és SZABó Csaba az Emberi Erőforrások Minisztériuma, ELTE Felsőoktatási Intézményi Kiválósági Program (1783-3/2018/FEKUTSRAT) támogatásában részesült.

\section{Irodalom - References}

AmmaR, M. R. \& RouZAUd, J.-N. 2012: How to obtain a reliable structural characterization of polished graphitized carbons by Raman microspectroscopy. - Journal of Raman Spectroscopy 43/2, 207-211. https://doi.org/10.1002/jrs.3014

ÁRKAI P. 1991: Chlorite crystallinity: an empirical approach and correlation with illite crystallinity, coal rank and mineral facies as exemplified by Paleozoic and Mesozoic rocks of northeast Hungary. - Journal of Metamorphic Geology 9, 723-734. https://doi.org/ 10.1111/j.1525-1314.1991.tb00561.x

ÁRKAI P. \& KovÁCS, S. 1986: Diagenesis and regional metamorphism of Aggtelek - Rudabánya Mountains (Northern Hungary). - Acta Geologica Hungarica 29, 349-373.

Árkai, P., FARYAD, S. W., VidAl, O. \& BAlOGH, K. 2003. Very low-grade metamorphism of sedimentary rocks of the Meliata unit, Western Carpathians, Slovakia: implications of phyllosilicate characteristics. - International Journal of Earth Sciences 92, 68-85. https://doi.org/10.1007/s00531-002-0303-x 
Aoya, M., Kouketsu, Y., Endo, S., Shimizu, H., Mizukami, T., Nakamura, D. \& Wallis, S. 2010: Extending the applicability of the Raman carbonaceous-material geothermometer using data from contact metamorphic rocks. - Journal of Metamorphic Geology 28/9, 895-914. https://doi.org/10.1111/j.1525-1314.2010.00896.x

BALOGH K. \& PANTó G. 1949: A Rudabányai-hegység földtani térképe 1:25 000. - A Magyar Állami Földtani Intézet kiadványa, Budapest. BALOGH K. \& PANTÓ G. 1952: A Rudabányai-hegység földtana. - A Magyar Állami Földtani Intézet Évi Jelentése az 1949. évról, 135-154.

BARKER, C. E. 1988: Geothermics of petroleum systems. Implications for stabilization of kerogen maturation after a geologically brief heating duration at peak temperature. In: MAGoon, L. (ed.): Petroleum Systems of the United States. - US Geological Survey Bulletin 1870, 26-29. https://doi.org/10.1007/978-1-4612-3492-0_5

BARZOI, S. C. 2015: Shear stress in the graphitization of carbonaceous matter during the low-grade metamorphism from the northern Parang Mountains (South Carpathians) - Implications to graphite geothermometry. - International Journal of Coal Geology 146, 179-187. https://doi.org/10.1016/j.coal.2015.05.008

BENY-BASSEZ, C. \& RouZAUd, J. 1985: Characterization of carbonaceous materials by correlated electron and optical microscopy and Raman microspectroscopy. - Scanning electron microscopy 1, 119-132.

BEYSSAC, O. \& LAZZERI, M. 2012: Application of Raman spectroscopy to the study of graphitic carbons in the Earth Sciences. - In: Dubessy, J., CAuMON, M.-C. \& Rull F. (eds): Raman spectroscopy applied to Earth sciences and cultural heritage. - EMU Notes in Mineralogy 12, 415-454. https://doi.org/10.1180/EMU-notes.12.12

Beyssac, O., Goffé, B., Chopin, C. \& Rouzaud, J. N. 2002: Raman spectra of carbonaceous material in metasediments: a new geothermometer. - Journal of Metamorphic Geology 20/9, 859-871. https://doi.org/10.1046/j.1525-1314.2002.00408.x

Beyssac, O., Goffé, B., Petitet, J.-P., Froigneux, E., Moreau, M. \& Rouzaud, J. N. 2003: On the characterization of disordered and heterogeneous carbonaceous materials by Raman spectroscopy. - Spectrochimica Acta Part A: Molecular and Biomolecular Spectroscopy 59/10, 2267-2276. https://doi.org/10.1016/S1386-1425(03)00070-2

Beyssac, O., Simoes, M., Avouac, J. P., Farley, K. A., Chen, Y.-G., Chan, Y.-C. \& Goffé, B. 2007: Late Cenozoic metamorphic evolution and exhumation of Taiwan. - Tectonics 26/6, TC6001. https://doi.org/10.1029/2006TC002064

Bustin, R. M., Ross, J. V. \& RouZAud, J. N. 1995: Mechanisms of graphite formation from kerogen: experimental evidence. - International Journal of Coal Geology 28/1, 1-36. https://doi.org/10.1016/0166-5162(95)00002-U

Crespo, E., LuQue, F. J., RodAs, M., WadA, H. \& GerVILla, F. 2006: Graphite-sulfide deposits in Ronda and Beni Bousera peridotites (Spain and Morocco) and the origin of carbon in mantle-derived rocks. - Gondwana Research 9/3, 279-290. https://doi.org/10.1016/j.gr.2005.10.003

DEÁK-KöVÉR, Sz. 2012: Structure, metamorphism, geochronology and deformation history of Mesozoic fromations in the central Rudabánya Hills. - PhD thesis, Eötvös Loránd University, 162 p.

FERrari, A. C. \& Robertson, J. 2001: Resonant Raman spectroscopy of disordered, amorphous, and diamondlike carbon. - Physical Review B 64/7, 075414. https://doi.org/10.1103/PhysRevB.64.075414

GriLl, J. 1988: Jurassic formations of the Rudabánya Mts. (in Hungarian with English abstract). - Annual Report of the Geological Institute of Hungary from 1986, 69-103.

GriLl J. 2012: Telekesoldali Formáció. In: Fôzy, I (szerk.): Magyarország litosztratigráfiai egységei. Jura. - Magyarhoni Földtani Társulat, Budapest, 136-138.

HATCHER, P. G. 1990: Chemical structural models for coalified wood (vitrinite) in low rank coal. - Organic Geochemistry 16/4, 959-968. https://doi.org/10.1016/0146-6380(90)90132-J

HATCHER, P. G. \& ClifFORD, D. J. 1997: The organic geochemistry of coal: from plant materials to coal. - Organic Geochemistry 27/5, 251-274. https://doi.org/10.1016/S0146-6380(97)00051-X

KoroKnAI, B. 2004: Tectonometamorphic evolution of the Uppony and Szendrő Paleozoic units. - PhD thesis, Eötvös University, 239 p. (in Hungarian with English abstract).

Kouketsu, Y., Mizukami, T., Mori, H., Endo, S., Aoya, M., Hara, H., Nakamura, D. \& Wallis, S. 2014: A new approach to develop the Raman carbonaceous material geothermometer for low-grade metamorphism using peak width. - Island Arc 23/1, 33-50. https:// doi.org/10.1111/iar.12057

KovÁCS, S. 1989: Geology of North Hungary, Paleozoic and Mesozoic terraines. - XXIst European Micropalaeontological Colloquium, Guidebook, Hungarian Geological Society, Hungary, Budapest, 1989, 15-37.

KöVÉR Sz., FODOR L. \& KovÁCS S. 2008: A Rudabányai-hegység jura képződményeinek szerkezeti helyzete és üledékes kapcsolata - régi koncepciók áttekintése és új munkahipotézis. - Annual Report of the Geological Institute of Hungary, 2006, 97-120.

KövÉR, Sz., Fodor, L., JudiK, K., NÉMETH, T., BALOGH, K. \& Kovács, S. 2009a: Deformation history and nappe stacking in Rudabánya Hills (Inner Western Carpathians) unravelled by structural geological, metamorphic petrological and geochronological studies. Geodinamica Acta 22, 3-29. https://doi.org/10.3166/ga.22.3-29

KöVÉr, Sz., HAAs, J., OzsvÁrT, P., GÖRÖG, Á., GÖTZ, A. E. \& JÓZSA, S. 2009b: Lithofacies and age data of Jurassic foreslope and basin sediments of Rudabánya Hills (NE Hungary) and their tectonic interpretation. - Geologica Carpathica 60/5, 351-379. https:// doi.org/10.2478/v10096-009-0027-y

KövÉr, Sz., Fodor, L., KovÁcs, Z., Klötzli, U., HaAs, J., ZaJZon, N. \& Szabó ,Cs. 2018: Late Triassic acidic volcanic clasts in different Neotethyan sedimentary mélanges: paleogeographic and geodynamic implications. - International Journal of Earth Sciences 107/8, 2975-2998. https://doi.org/10.1007/s00531-018-1638-2

Laufente, B., Downs, R., Yang, H. \& Stone, N. 2015: The power of databases: the RRUFF project. In: "Highlights in mineralogical crystallography", Armbruster, T. \& Danisi, R. M. (eds.) W. - De Gruyter, Berlin, Germany 1,30. https://doi.org/10.1515/9783110417104-003

Lahfid, A., Beyssac, O., Deville, E., Negro, F., Chopin, C. \& Goffé, B. 2010: Evolution of the Raman spectrum of carbonaceous material in low-grade metasediments of the Glarus Alps (Switzerland). - Terra Nova 22/5, 354-360. https://doi.org/10.1111/j.13653121.2010.00956.x 
Less Gy., Grill J., Szentpétery I., Róth L. \& Gyuricza Gy. 1988: Az Aggtelek-Rudabányai-hegység fedetlen földtani térképe. M=1:25 000. - A Magyar Állami Földtani Intézet kiadványa, Budapest.

Liu, D., XiaO, X., Tian, H., Min, Y., Zhou, Q., Cheng, P. \& Shen, J. 2012: Sample maturation calculated using Raman spectroscopic parameters for solid organics: Methodology and geological applications. - Chinese Science Bulletin 58/11, 1285-1298. https://doi.org/ 10.1007/s11434-012-5535-y

LÜNSDORF, N. K. 2016: Raman spectroscopy of dispersed vitrinite - Methodical aspects and correlation with reflectance. - International Journal of Coal Geology 153, 75-86. https://doi.org/10.1016/j.coal.2015.11.010

LÜNSDORF, N. K. \& LÜNSDORF, J. O. 2016: Evaluating Raman spectra of carbonaceous matter by automated, iterative curve-fitting. International Journal of Coal Geology 160-161, 51-62. https://doi.org/10.1016/j.coal.2016.04.008

Lünsdorf, N. K., Dunkl, I., Schmidt, B. C., Rantitsch, G. \& von Eynatten, H. 2014: Towards a Higher Comparability of Geothermometric Data obtained by Raman Spectroscopy of Carbonaceous Material. Part I: Evaluation of Biasing Factors. Geostandards and Geoanalytical Research 38/1, 73-94. https://doi.org/10.1111/j.1751-908X.2013.12011.X

Lünsdorf, N. K., Dunkl, I., Schmidt, B. C., Rantitsch, G. \& von Eynatten, H. 2017: Towards a Higher Comparability of Geothermometric Data Obtained by Raman Spectroscopy of Carbonaceous Material. Part 2: A Revised Geothermometer. - Geostandards and Geoanalytical Research 41/4, 593-612. https://doi.org/10.1111/ggr.12178

MCCREERY, R. L. 2005: Raman spectroscopy for chemical analysis. - John Wiley \& Sons. Inc. ISBN 0-471-25287-5

MÉszáros E., RAucsiK B., Raucsikné VARGA A. \& SChUberT F. 2016: Kisfokú, közepes nyomású regionális metamorfózis nyomai a Horváthertelend-1 fúrás metapelites összletében: mikroszöveti és termobarometriai bizonyítékok. - Földtani Közlöny 146/3, $207-222$.

Oberlin, A. \& Bonnamy, S. 1989: High-Resolution TEM studies of carbonization and graphitization. - In: THRower P. A. (ed.): Chemistry and Physics of Carbon. London, New York, 22, 1-114.

Oberlin, A. \& Bonnamy, S. 2013: A Realistic Approach to Disordered Carbons. - In: RADovic, L. R. (ed.): Chemistry and Physics of Carbon. p. 297. https://doi.org/10.1201/b12960-2

Oberlin, A., Bonnamy, S. \& Rouxchet, P. G. 1999: Colloidal and Supramolecular Aspects of Carbon. - In: Thrower, P. A. \& RAdovic, L. R. (eds): Chemistry and Physics of Carbon. p. 26, 424.

PASTERIS, J. D. \& WopenKA, B. 1991: Raman spectra of graphite as indicators of degree of metamorphism. - The Canadian Mineralogist 29/1, 1-9.

Pimenta, M. A., Dresselhaus, G., Dresselhaus, M. S., Cançado, L. G., Jorio, A. \& Saito, R. 2007: Studying disorder in graphitebased systems by Raman spectroscopy. - Physical Chemistry Chemical Physics 9/11, 1276-1290. https://doi.org/10.1039/B613962K

Pócsik, I., Hundhausen, M., Koós, M. \& Ley, L. 1998: Origin of the D peak in the Raman spectrum of microcrystalline graphite. Journal of Non-Crystalline Solids 227-230, 1083-1086. https://doi.org/10.1016/S0022-3093(98)00349-4

Rahl, J. M., ANDERSON, K. M., BrAndon, M. T. \& FAssoulas, C. 2005: Raman spectroscopic carbonaceous material thermometry of low-grade metamorphic rocks: Calibration and application to tectonic exhumation in Crete, Greece. - Earth and Planetary Science Letters 240/2, 339-354. https://doi.org/10.1016/j.eps1.2005.09.055

Rantitsch, G., Grogger, W., Teichert, C., Ebner, F., Hofer, C., Maurer, E.-M., Schaffer, B. \& Toth, M. 2004: Conversion of carbonaceous material to graphite within the Greywacke Zone of the Eastern Alps. - International Journal of Earth Sciences $\mathbf{9 3 / 6}$, 959-973. https://doi.org/10.1007/s00531-004-0436-1

RosASCO, G. J. \& RoEDDER, E. 1979: Application of a new Raman microprobe spectrometer to nondestructive analysis of sulfate and other ions in individual phases in fluid inclusions in minerals. - Geochimica et Cosmochimica Acta 43/12, 1907-1915. https://doi.org/ 10.1016/0016-7037(79)90004-8

Rossman, G. R. 2006: Analytical methods for measuring water in nominally anhydrous minerals. - Reviews in Mineralogy and Geochemistry 62, 1-28. https://doi.org/10.2138/rmg.2006.62.1

Sadezky, A., Muckenhuber, H., Grothe, H., Niessner, R. \& Pöschl, U. 2005: Raman microspectroscopy of soot and related carbonaceous materials: Spectral analysis and structural information. - Carbon 43/8, 1731-1742. https://doi.org/10.1016/ j.carbon.2005.02.018

Scharf, A., HANDY, M. R., ZiEmann, M. A. \& SCHMID, S. M. 2013: Peak-temperature patterns of polyphase metamorphism resulting from accretion, subduction and collision (eastern Tauern Window, European Alps) - a study with Raman microspectroscopy on carbonaceous material (RSCM). - Journal of Metamorphic Geology 31/8, 863-880. https://doi.org/10.1111/jmg.12048

SZENTPÉTERY I. \& LESS Gy. 2006: Az Aggtelek-Rudabányai-hegység földtana. Magyarország tájegységi térképsorozata. - MÁFI Kiadvány, 92 o.

Taylor, G. H., Teichmüller, M., Davis, A., Diessel, C., LittKe, R. \& Robert, P. 1998: Organic petrology. - Gebrüder Bonrtraeger, Berlin. ISBN 978-3-443-01036-2

VÁCZI T. 2011: Raman-spektroszkópia. - In: VÁcZI T. (szerk.): Nanometrológia. Miskolc, 243-297.

VidANO, R. P., FISCHBACH, D. B., Willis, L. J. \& LoEHR, T. M. 1981: Observation of Raman band shifting with excitation wavelength for carbons and graphites. - Solid State Communications 39/2, 341-344. https://doi.org/10.1016/0038-1098(81)90686-4

WOPENKA, B. \& PASTERIS, J. D. 1993: Structural characterization of kerogens to granulite-facies graphite: Applicability of Raman microprobe spectroscopy. - American Mineralogist 78/5-6, 533-557.

Kézirat beérkezett: 2020. 04. 17. 